\title{
Intercultural Competence in Teaching: Defining the Intercultural Profile of Student Teachers
}

\author{
Marta Garrote Salazar \& María Fernández Agüero \\ Universidad Autónoma de Madrid, Spain \\ Article received 13 May 2016, accepted 3 November 2016, final version 16 December 2016 \\ DOI: http://dx.doi.org/10.5565/rev/jt13.670
}

\begin{abstract}
This article describes the intercultural profile of European student teachers in order to clarify the relationship between Intercultural Competence (IC) and teacher training. The main tool used for that was a questionnaire to assess IC, following the criteria established by the Intercultural Competence Assessment (INCA) Project in which IC levels are ranked. The survey poses a variety of personal and professional situations where IC comes into play and different responses to choose from, ranging from insufficiently intercultural to highly intercultural. The results of this study show that most European student teachers participating in the research displayed an intermediate level of IC, which indicates a necessity to improve future teachers' IC training, particularly highlighting IC dimensions such as behavioural flexibility or communicative awareness.
\end{abstract}

Keywords: Intercultural Competence, teacher training, student teachers

\begin{abstract}
Resumen
Este artículo describe el perfil intercultural de futuros docentes europeos con la intención de esclarecer la relación entre la Competencia Intercultural (CI) y la formación docente. La principal herramienta utilizada para ello ha sido un cuestionario que evalúa la CI, siguiendo el criterio establecido por el Proyecto Intercultural Competence Assessment (INCA) en el cual se clasifican distintos niveles de CI. La encuesta plantea diferentes situaciones personales y profesionales donde la CI entra en juego y da varias respuestas a elegir, desde la considerada insuficientemente intercultural hasta la altamente intercultural. Los resultados muestran que la mayoría de los futuros docentes europeos que participaron en el estudio manifestaron un nivel intermedio de CI, lo que indica una necesidad de mejorar la formación en CI de los futuros docentes, especialmente en lo que se refiere a aspectos como la flexibilidad de conducta o la conciencia comunicativa.
\end{abstract}

Palabras clave: Competencia Comunicativa, formación docente, futuros docentes

\section{Resum}

Aquest article descriu el perfil intercultural de futurs docents europeus amb la intenció de clarificar la relació entre la Competència Intercultural (CI) y la formació docent. S'ha utilitzat com a eina principal un qüestionari que avalua la CI, seguint el criteri establert pel Projecte Intercultural Competence Assessment (INCA) en el qual es classifiquen els diferents nivells de CI. L'enquesta planteja diferents situacions personals i professionals on la CI entra en joc i proposa vàries respostes a escollir, des de la considerada insuficientment intercultural fins a l'altament intercultural. Els resultats mostren que la majoria dels futurs 
docents europeus que varen participar en l'estudi, varen manifestar un nivell intermedi de CI, el que manifesta la necessitat de millorar la formació en CI dels futurs docents, especialment en tot el que fa referència a aspectes com la flexibilitat de conducta o la consciència comunicativa.

Paraules clau: Competència Comunicativa, formació docent, futurs docents

\section{Introduction}

The objective of this article is to contribute to the analysis of interculturality and, eventually, to its promotion by unfolding the notion of Intercultural Competence (IC) in the context of European education -taking IC as 'the ability to interact effectively with people of cultures other than one's own' (Byram, 2000, p. 297) ${ }^{1}$. In particular, we aim to measure the IC profile of a group of European young student teachers in pre-service training, according to the parameters of the European Intercultural Competence Assessment (INCA) Project, a proposal for the assessment of IC linked to language and subject knowledge competence that builds on Michael Byram's framework for IC learning (1997; 2009), thoroughly explained below.

The grounds for the present research rest upon a pilot study (Alonso-Belmonte, Fernández-Agüero, Garrote \& Morcillo, 2014) whose aim was to assess IC in a group of prospective teachers at Universidad Autónoma de Madrid. That study yielded a series of contradictions in the subjects' discourse, particularly between their professional and personal lives, that pointed at the need to draw a broader picture on the intercultural profile of teaching trainees. We believe that this line of enquiry will help identify possible shortcomings in teacher training from an intercultural perspective, so that teachers-to-be become 'intercultural speakers' (Kramsch, 1993), who are able to 'decentre', to see intercultural encounters from an outsider's perspective (Byram, Gribkova \& Starkey, 2002, p. 12).

In the multicultural context of Europe, a community which 'sets a high value on its diversity, which is European because of and not in spite of this diversity' (Vez, 2009, p. 12), approaching education from an intercultural standpoint is a must: research in intercultural education has brought to light that there is a demand for teachers in Europe who can appreciate and take part in the continent's rich cultural environment (for instance, Aguado, Ballesteros \& Malik, 2003; Alkan \& de Vredee, 1990; Lanas, 2014; Cavalli, Coste, Crişan \& van de Ven, 2009). However, training in IC is still ineffective in certain respects. To begin with, it is usually associated with second language (L2) learning. Most certainly, there is an inseparable link between the ability to function effectively in an L2 and the collection of skills, knowledge and attitudes that contribute to IC (Byram, 1997), and the L2 classroom is the 
most suitable milieu for its development (Costa, 2011). Nevertheless, plenty of studies report on language teachers', teacher trainers' and curriculum developers' insecurities and difficulties in the implementation of IC (for example, Clouet, 2012; Young \& Sachdev, 2011); on classroom practices where language overrides IC (Sercu, 2010); and on teachers' inadequate intercultural profile for teaching languages (Sercu, 2006). Also, IC training has a bearing in professional settings such as health care and business, but even there, IC is still unfamiliar for teachers and curriculum developers (Dogra, 2007). Other studies concerning IC across the general teacher training curriculum tend to report difficulties for teachers too (Dunn, Kirova, Cooley \& Ogilvie, 2009). In any case, there is a dearth of literature addressing the holistic comprehensive treatment of IC in teacher training.

To gain an insight into the degree of interculturality of prospective European teachers and devise possible remedial actions in IC training, this study will gauge the IC of 109 preservice teachers from 6 European universities through a tailor-made survey with the aim of describing the general profile of European student teachers and some of the factors that contribute to the development of this given profile.

\section{Theoretical background}

\section{The concept of IC and IC training}

In the last decades, scholars have proposed a number of definitions for IC (see Spitzberg \& Changnon, 2009 for a review) and have put forward several models in an attempt to identify its components and their interrelation, and to limit its scope (Byram, 1997; 2009; Byram \& Zarate, 1997; Chen \& Starosta, 1996; Deardorff, 2006, 2009; Fantini, 2000; Moran, 2001; Ting-Toomey, 1999; to name a few). Still, more than twenty years after Brent Ruben's plea for a 'need for conceptual clarity' (1989, p. 234), research in this area suffers from conceptual ambiguity and the lack of completely valid and reliable assessment instruments.

Nevertheless, a certain consensus has been reached. The literature has reflected a shift from a stand where IC was seen as an individual ability related to effectiveness or appropriateness in interaction -as in the work by Ruben and Kealey, for example (Ruben, 1977; Ruben \& Kealey, 1979; Kealey, 1989) - towards IC being regarded as a blend of three interrelated and equally important constituents, namely behaviour, cognition and affection, that are expressed through internal and external outcomes (Deardorff, 2006). It is now generally acknowledged that, observable behavioural traits notwithstanding, interculturally competent individuals must possess the capacities (1) to act appropriately and effectively in 
the intercultural encounter, (2) to know about their own and their interlocutor's cultural conventions, and (3) to demonstrate positive feelings towards cultural difference. This trio is frequently referred to as intercultural skills, knowledge and attitudes, a set of savoirs (Byram, 1997) or dimensions of knowledge about the general processes involved in interaction and about how social groups might behave (Table 1).

Table 1. Byram's dimensions of IC (Source: Alonso-Belmonte and Fernández-Agüero, 2013, p. 191)

\begin{tabular}{ll}
\hline Component & \multicolumn{1}{c}{ Definition } \\
\hline Knowledge (savoir) & $\begin{array}{l}\text { Knowing the system of cultural references of social } \\
\text { groups (their products and practices) in one's own } \\
\text { culture and other cultures, and knowing about social } \\
\text { and individual interactions. }\end{array}$ \\
\hline Attitude (savoir être) & $\begin{array}{l}\text { Having the affective capacity to overcome } \\
\text { ethnocentrism and the cognitive capacity to establish } \\
\text { and maintain a relationship between one's own } \\
\text { culture and others. }\end{array}$ \\
\hline $\begin{array}{l}\text { Interpreting and } \\
\text { relating (savoir } \\
\text { comprendre) }\end{array}$ & $\begin{array}{l}\text { The ability to interpret a document or event in other } \\
\text { culture, explain it and relate it to one's own culture. }\end{array}$ \\
\hline $\begin{array}{l}\text { Discovering and } \\
\text { interacting (savoir } \\
\text { apprendre/faire) }\end{array}$ & $\begin{array}{l}\text { The ability to create an interpretative system of the } \\
\text { meanings, beliefs and cultural practices that we get to } \\
\text { know, coming from unknown cultures or not. }\end{array}$ \\
\hline $\begin{array}{l}\text { Critical cultural } \\
\text { awareness (savoir } \\
\text { s'engager) }\end{array}$ & $\begin{array}{l}\text { The ability to evaluate critically perspectives, } \\
\text { practices and products of one's own culture and other } \\
\text { cultures on the basis of explicit criteria. }\end{array}$ \\
\hline
\end{tabular}

In his model, critical cultural awareness is at the core of IC (Byram, 2009). Similarly, Fantini (2000) adds intercultural awareness to the cluster of components of IC, emanating from the other components, while enhancing their development at the same time. From their part, Chen and Starosta (1996) put forward their triangular model of intercultural communicative competence, which includes intercultural awareness, intercultural sensitivity and intercultural adroitness, referring to cognition, affective skills and behaviour respectively ${ }^{2}$. On the other hand, Hammer, Bennett \& Wiseman (2003, p. 422) draw a major distinction between intercultural sensitivity ('the ability to discriminate and experience relevant cultural differences') and intercultural competence ('the ability to think and act in interculturally appropriate ways'), and measure interculturality through the Intercultural Development Inventory (IDI; Hammer \& Bennett, 2001). Interestingly, Arasaratnam and Doerfel (2005) propose a bottom-up approach to the characterisation of IC: through the analysis of the answers of 37 interculturally competent individuals to a set of prompts related to their own cultures, they conclude that interculturally competent individuals possess five qualities across cultures: empathy, intercultural experience/training, motivation, global attitude, and ability to listen well in conversation. 
The exact relationship among the dimensions of IC, and the extent to which they are to be developed in fully competent individuals remains unclear. In any case, it is generally believed that only through IC can people from different cultures achieve their goals effectively and appropriately in the process of intercultural interaction. Unfortunately, IC is not developed spontaneously in most people; quite the contrary, this development is an ongoing and lengthy lifelong process along which individuals may even experience occasional moments of regression or blockage. For these reasons, IC has to be tackled as a learning objective in class (Deardorff 2009, p. 13). Moreover, it should be a cross curricular endeavour carried out by interculturally competent teachers, as there is a tight link between teachers' IC and teaching effectiveness (Villegas \& Lucas, 2002). More than just a buzz-word, interculturality need to be a major trend that must be broken down into a series of principles endorsed by teachers and education authorities alike, among which these stand out: the students' cultural heritage is to be taken as the starting point, granting equal value to all students' cultural knowledge; students should be made aware that their cultural representations are provisional and dynamic; and reality should be examined by applying ethical judgement in relation to bias, stereotype and prejudice, ethnocentrism, and conventional cultural knowledge. IC assessment, on the other hand, should be based on a mix of qualitative and quantitative methods including interviews, observation, portfolios, as well as self and peer review (Deardorff, 2006).

Yet, the study of IC still poses a number of major challenges, especially in relation to the role that IC plays in the widespreading notion of global communication competence: for example, how IC contributes to building a global civic culture (Ashwill \& Duong, 2009) and how globalisation influences the autonomy and stability of traditional cultural identities (Collier, 2005). The question remains whether IC teaching can go global but somehow remain local and relate to the students' experiences at the same time.

\section{Interculturality in Europe}

Education stakeholders in Europe are devoting big efforts to spread a sense of European 'togetherness' through countless initiatives such as, say, transnational mobility Erasmus+ programmes, with a twofold aim: maintaining Europeans' distinct home-culture attributes and developing a supra-national European identity. The idea of pluriligualism and the adoption of a 'second mother tongue' apart from English -which is assumed as a lingua franca but imposes tangible threats over other European linguistic identities- go along these lines too 
(Breidbach, 2003, p. 18ff.). In this vein, the seminal document Common European Framework of References for Languages: Learning, Teaching, Assessment (Council of Europe, 2001) discusses the features of the 'intercultural speaker', an individual who possesses a pluricultural competence to participate adequately in intercultural relations.

Concerning teacher training, European institutions such as the Council of Europe are going out of the way to instil an 'intercultural feel' in the teaching community, especially through the European Centre for Modern Languages in Graz, and in relation to L2 learning (for instance Byram et al., 2002; Lázár, 2003; Lázár, Huber-Kriegler, Lussier, Matei \& Peck, 2007). More specifically, Byram's model of IC (1997; 2009), briefly described above, has a clear pedagogic orientation and has made an impact over L2 teaching and teacher training (Alred, Byram \& Fleming, 2003; Byram \& Fleming, 1998; Byram \& Phipps, 2007; among others). Other compelling European initiatives to teach and test IC are the Autobiography of Intercultural Encounters, published by the Language Policy Division of the Council of Europe in 2007 (http://www.coe.int/t/dg4/autobiography/default_en.asp); the guide for higher education Intercultural Learning for European Citizenship (Gifford, Gocsal, Rado, Gonçalves \& Wołodźko, 2009); and the splendid collections of materials for young students Intercultural Learning T-Kit (Martinelli, 2000) and All Different, All Equal (Taylor, Brander, Cárdenas, Gomes \& de Vicente Abad, 1995). These proposals point at a tendency towards the conceptual development of IC in in-service teacher training and its implementation in specific teaching contexts in Europe.

On the other hand, teacher training provisions for IC training in Europe cover a wide spectrum of educational experiences, different in scope and content, from international business schools to medical training; from short modules for cross-cultural mediation to whole Masters' in Intercultural Education; from short study-abroad university courses to permanent residency programmes. This signals a special interest in IC, which is, nevertheless, unsystematic and, to a certain extent, erratic. Still, the current social and cultural landscape in Europe -striking demographic changes, social inequalities between and within countriescalls for critical engagement in social justice among the European teaching community, which IC training can hopefully contribute to.

\section{The current study}

Given the current relevance of interculturality in social research and, especially, its undeniable connection to teaching, the present study delves into a group of European pre- 
service teachers' profile regarding IC. The significance of the research falls not only on the description of that profile, but also on unveiling students' needs to acquire full competence. Consequently, this work will address the following research questions:

(1) What is student teachers' IC profile like in the European context?

Taking into account globalisation, the extensive use of information and communication technology and the convergence of cultures in Europe, we foretell a medium-high IC. Nonetheless, the pilot study by Alonso-Belmonte et al. (2014), which laid the foundations of the present research, already suggested contradictions in the participants' discourse, which may lead to a different outcome.

(2) What dimensions of IC are these student teachers more skilled in?

Following Byram's dimensions of IC (Table 1), we predict that student teachers will display higher proficiency regarding knowledge as this dimension can be more easily achieved through instruction and hypothesising whereas modelling attitudes and skills may require experiencing and exposure to intercultural situations. Indeed, according to Fantini (2000), knowledge and skills are usually dealt with in traditional educational settings, but attitudes are overlooked.

(3) What factors have an influence on this profile?

It is anticipated that variables such as having been abroad, speaking more than two languages or even sex result in different outcomes. In fact, previous studies (Martin, 1987; Williams, 2005) suggest a positive influence of foreign sojourns in IC. We expect our data to shed some light on the relationship between IC and the variables taken into account.

(4) What is this profile like in the students' personal and professional lives? We anticipate that student teachers will show a higher degree of IC in professional environments due to work demands and awareness of their teaching responsibility. This idea comes from a previous study (Alonso-Belmonte et al., 2014), according to which pre-service teachers felt a release of responsibility in their personal lives while admitted making an effort in professional settings.

\section{Methodology}

The present study is a piece of quantitative research which statistically analyses data collected through a questionnaire. The questionnaire was designed ad hoc for this investigation following the Intercultural Competence Assessment (INCA) Project (2004), a method to assess IC grounded on Michael Byram's framework for IC learning (1997; 2009). Having in 
mind the assessee manual (described below), we look into IC dimensions (knowledge, skills and attitudes), evaluating respondents' scores and their relationship with variables such as nationality, age or number of languages spoken by the participants.

\section{The INCA framework}

The INCA framework, which makes up the methodological underpinnings of this study, draws from a Leonardo Da Vinci II European project led by Michael Byram in 2001-2004 whose aim was to define a multidimensional framework for the assessment of $\mathrm{IC}^{3}$. Initially developed and tested for L2 teaching in the engineering sector (Prechtl \& Davidson-Lund, 2007), it puts forth a series of diagnostic instruments for IC assessment, called the INCA scales. From the point of view of the assessor, it defines IC in relation to six dimensions: tolerance of ambiguity, behavioural flexibility, communicative awareness, knowledge discovery, respect for otherness and empathy. For each dimension, three competence levels are described: basic, intermediate and full. For example, Table 2 portrays the different levels for 'tolerance of ambiguity':

Table 2. INCA levels for 'tolerance of ambiguity'

\begin{tabular}{|c|c|}
\hline & Tolerance of ambiguity \\
\hline Basic & Intermediate \\
\hline $\begin{array}{l}\text { Deals with ambiguity on a one-off } \\
\text { basis, responding to items as they } \\
\text { arise. May be overwhelmed by } \\
\text { ambiguous situations which imply } \\
\text { high involvement. }\end{array}$ & 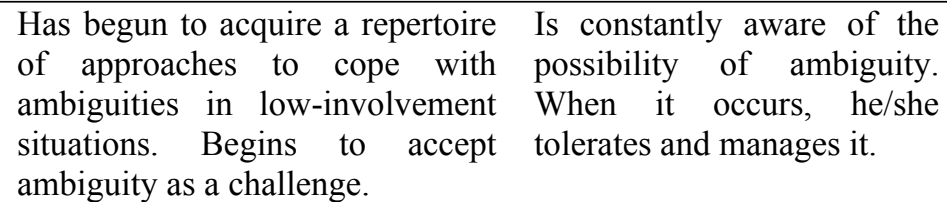 \\
\hline
\end{tabular}

Besides, there is a simplified grid for the assesse (INCA Assessee Manual), which guided the design of our research tool, with three macro-components -openness, knowledge and adaptability-, broadly related to attitudes, knowledge and skills respectively (Table 3 ).

Table 3. INCA Assessee Manual, (2004, p. 4)

\begin{tabular}{ll}
\hline Macro-component & \multicolumn{1}{c}{ Characteristics } \\
\hline Openness & Tolerance of ambiguity and respect for otherness. \\
Knowledge & Knowledge discovery and empathy. \\
Adaptability & Behavioural flexibility and communicative awareness. \\
\hline
\end{tabular}

The levels and dimensions are expressed in plain understandable terms for the assessee, in the fashion of 'can do' statements.

\section{Survey design}

The information needed to shed light on these questions was gathered through a survey, based on a questionnaire made up of 8 identifying questions (see Figure 1) and 22 multiple-choice 
questions, 11 related to situations in the personal domain and 11 concerning the professional domain.

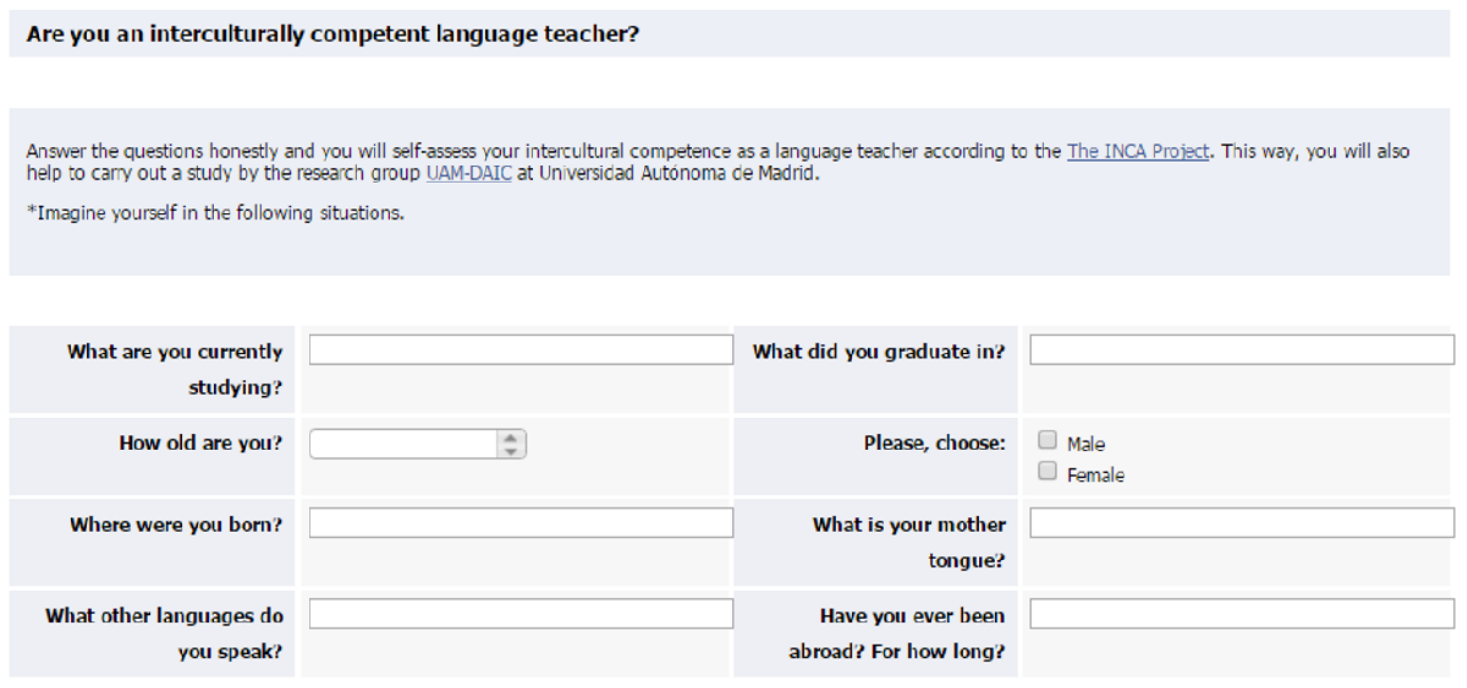

Figure 1. Identifying questions

Both personal and professional sections have two overview of competence questions and nine questions related to INCA assessee's dimensions of IC, namely, openness, knowledge and adaptability. Respondents had to choose among four options with a value of either 1 (neutral profile), 2 (basic profile), 3 (intermediate profile) or 4 (full profile) points. The total punctuation of the questionnaire is 88 points (see Table 4 ).

Table 4. Survey ranks

\begin{tabular}{lc}
\hline Profile & Punctuation \\
\hline Neutral competence & $0-33$ points \\
& $(37.5 \%)$ \\
Basic competence & $34-55$ points \\
& $(62.5 \%)$ \\
Intermediate & $56-77$ points \\
competence & $(87.5 \%)$ \\
Full competence & $78-88$ points \\
& $(100 \%)$ \\
\hline
\end{tabular}

The questions described hypothetical intercultural situations to which respondents had to choose their most likely behavioural reaction. Figures 2 and 3 show examples from the personal and professional domains respectively. 


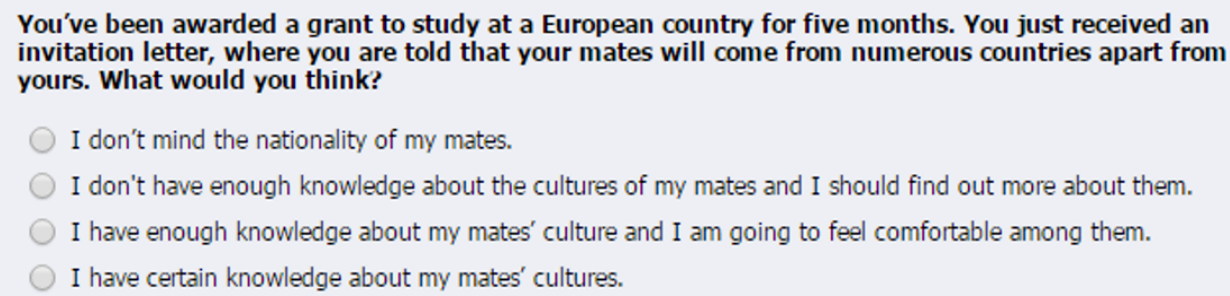

Figure 2. Personal domain hypothetical situation

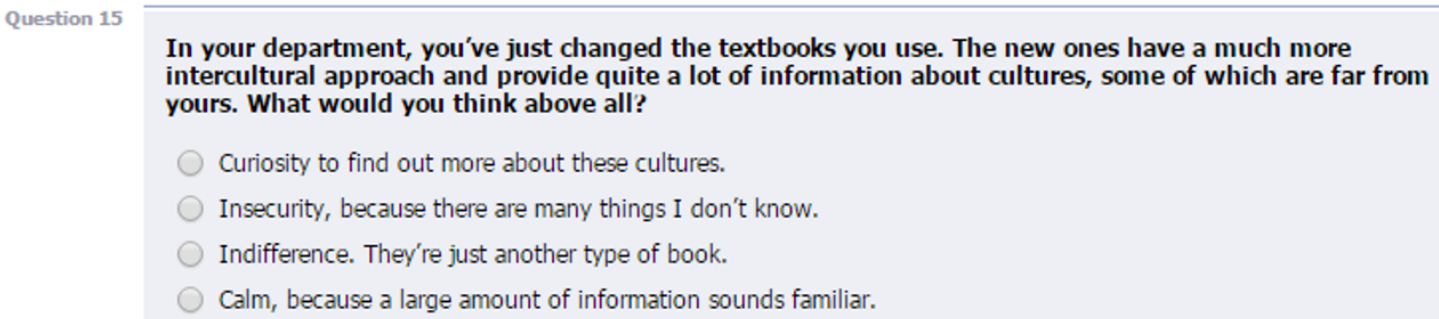

Figure 3. Professional domain hypothetical situation

Thanks to the precise 'can do' statements addressed to the assessee mentioned above, we could provide respondents with comprehensible feedback on their IC profile in return for the data.

\section{Data management}

The questionnaire was digitalised using the web-based application QuestBase (www.questbase.com) which provides easy access, facilitates data management and allows for immediate feedback about the respondent's IC profile. The participants were 109 students of Education from 6 European institutions -Eötvös Loránd University (Hungary), Institute of Education (University of London, UK), University of South Bohemia (Czech Republic), Saxion University of Applied Sciences (The Netherlands), Çukurova University (Turkey $\left.{ }^{4}\right)$ and Universidad Autónoma de Madrid (Spain). Participants were informed by their university professors about the aim of the research and were asked to fill the questionnaire online.

The independent variables were the nationality of the subjects, their age and sex, number of languages spoken, having been abroad and for how long and having received specific training on IC. The dependent variables were the punctuations in the questionnaire, both final and partial marks for the different sections (personal and professional domains) and, within these, questions related to openness, knowledge, adaptability and overview of competence.

Data were organized in an SPSS (IBM SPSS Statistics 22) database and missing 
values were replaced using the automatic method median of nearby points with a span of 4 points. Frequency and descriptive statistics were used to give an account of the sample. Although the dependent variables are scale variables and the number of participants is $n=109$, the distribution of the sample is not normal, according to the Kolmogorov-Smirnov Test $(\mathrm{p}<$ $0.05)^{5}$. Therefore, the tests used for the analysis are nonparametric.

Regarding statistical tests, we applied Chi-square test to establish the distribution of categorical variables (as distribution of sex according to nationality or having been abroad); Wilcoxson test to observe differences between two related samples and Mann-Whitney U test for two independent samples; and Kruskal-Wallis $\mathrm{H}$ test to establish if there was a relationship between several independent variables.

\section{Results}

Regarding descriptive statistics, the mean age was 22 years old $(\overline{\mathrm{X}}=22.7, \mathrm{~s}=3.2)$ and the sex distribution was $20.4 \%$ males and $79.6 \%$ females. Table 5 shows the figures related to the number of languages spoken by the participants. Almost half of them spoke two languages apart from their mother tongue and $73.5 \%$ had been abroad $(24.8 \%$ for weeks, $38.9 \%$ for months and $9.7 \%$ for years). Just $3.5 \%$ of them affirmed having received training on IC.

Table 5. Foreign languages spoken

\begin{tabular}{cl}
\hline Foreign languages & Percent \\
\hline 1 & 39.8 \\
2 & 44.2 \\
3 & 14.2 \\
4 & 1.8 \\
\hline
\end{tabular}

The results related to INCA profiles (neutral, basic, intermediate and full competence) can be seen in Table 6 , according to which $97.3 \%$ of respondents displayed an intermediate level of IC.

Table 6. INCA profile

\begin{tabular}{lc}
\hline INCA profile & Percent \\
\hline Neutral & 0.0 \\
Basic & 2.7 \\
Intermediate & 97.3 \\
Full & 0.0 \\
\hline
\end{tabular}

The Chi-square test result $(\mathrm{p}>0.05)$ proved that there was no difference between males' and females' punctuation in relation to nationality, the number of L2s spoken and having been abroad.

Concerning the punctuation obtained for IC in personal and professional domains, Wilcoxon test proved that the difference between means is significant at a confidence interval 
of $99 \%(p=0.01)$, which means that IC increases in students' professional environment. In their personal domain, student teachers portrayed lower competence when facing intercultural contexts where a conflict might arise.

However, when dissecting data, the results of the Wilcoxon test were not totally consistent with those obtained for the two domains, personal and professional. Regarding openness, there was a difference between means $(\mathrm{p}<0.05)$, this being higher in the professional context (6.5 vs. 5.8); and the same phenomenon was registered for adaptability. However, there was no significance in the test for knowledge, the means being equal for the personal and professional domains. This suggests that regarding knowledge, subjects were equally competent in their personal and professional life. On the contrary, their openness and adaptability was lower in their daily life.

According to Mann-Whitney $U$ test, there was no relationship between sex and IC. Without being significant, the higher difference in means was shown in adaptability in the personal domain, where male participants' mean was 12.9, whereas women's was 11.9. Surprisingly, having been abroad and IC training made no difference in their IC.

Finally, concerning the possible significant differences in final or partial marks grouping subjects by their nationalities or the number of L2s they spoke, the Kruskal-Wallis $\mathrm{H}$ test revealed that nationality affected punctuation, but not the number of L2s. Table 7 presents the different punctuations in relation to nationality.

Table 7. Punctuation mean according to nationality

\begin{tabular}{lccc}
\hline Nationality & Personal domain & Professional domain & Total punctuation \\
\hline Czech Republic & 32 & 34 & 66 \\
United Kingdom & 32 & 34 & 66 \\
Hungary & 33 & 35 & 68 \\
Netherlands & 32 & 35 & 67 \\
Spain & 36 & 36 & 73 \\
Turkey & 34 & 35 & 69 \\
\hline
\end{tabular}

Concluding, the higher mean corresponds to Spain (73 points out of 88). The last position is for the Czech Republic and England (66 points both). None of the subjects reached the highest INCA profile (full competence). The countries participating remained in an intermediate IC position, The Netherlands showing a more significant difference between IC in personal and professional environments.

\section{Discussion}

Results lead us to the following reflections, in relation to our research questions: as predicted, 
these student teachers' IC profile is mostly intermediate $(97.3 \%$ of subjects, and total sample punctuation $\bar{X}=68.1$ ), which indicates that training is still required to successfully face intercultural encounters in their future teaching practice, especially for those respondents with a basic profile $(2.7 \%)$. This is in line with other studies that measure teachers' IC (Yuen, 2010). The results imply that teacher trainers must prepare their students in the fashion outlined in section devoted to the concept of IC and IC training, but also infuse trainees with an intercultural awareness that can drive self-learning (as in models such as Dooly \& Villanueva, 2006).

Regarding differences among nationalities, a thorough research would be necessary to enquire into social and educational factors that could influence the results. According to the 2014 report by the statistical office of the European Union (http://ec.europa.eu/eurostat), the Czech Republic has a low rate of non-national population, which could lead to a lower exposure to intercultural experiences. However, the UK's and Spain's high rates of nonnational population do not serve to explain their dissimilar punctuations on the survey. In the absence of sufficient data, this matter remains unanswered.

Concerning the dimensions of IC, respondents showed a high competence in both personal and professional domains regarding knowledge. However, their punctuation was lower in openness and adaptability, which confirms our prediction and points at the importance to address these components in IC training. As mentioned, knowledge and skills are customarily addressed in traditional educational settings, but attitudes and awareness are somehow neglected, and stating IC levels in behavioural terms helps designing a progression to assure IC attainment (Fantini, 2000, p. 30). Nevertheless, we advocate for the implementation of comprehensive approaches to IC teaching such as the ones presented in section on Interculturality in Europe above.

Contrary to our expectations, in our data, neither foreign sojourns nor IC training have an influence on the current study respondents' profile. Although $73.5 \%$ of respondents had been abroad, mostly for months (38.9\%); this seemed to exert no influence over their IC profile, which contradicts the findings of previous studies (Martin, 1987; Williams, 2005) according to which sojourners tend to exhibit a higher intercultural profile. In this respect, further research could dig into IC and the nature of intercultural experiences abroad -the degree of involvement in the foreign community's daily life, for instance. As for having received IC training, conclusive explanations could be derived from looking into the kind of training that respondents received, which is expectedly disparate since IC instruction is 
heterogeneous throughout Europe. In any case, we foresee a relationship between this outcome and the need for building up training on IC dimensions other than knowledge, that is, respect for others, tolerance of ambiguity, behavioural flexibility and communicative awareness.

Results reveal no influence of the male-female variable on IC profile, as seen in previous research (Hammer et al., 2003). Only a slightly higher mean of men in adaptability in the personal domain was found.

Finally, as predicted, different figures regarding personal and professional domains, particularly in relation to openness and adaptability, evidence that students felt a certain sense of 'intercultural responsibility' as professionals, that they were aware of their professional duty to be intercultural at school. As the punctuation for openness and adaptability decreased in the personal domain $(\bar{X}=31.1)$ with respect to the professional one $(\bar{X}=34.8)$, while knowledge remained the same in both domains, it seems that these students felt a sort of release of responsibility in the personal domain: they had the required knowledge but did not feel the need to apply it (Alonso-Belmonte et al., 2014) through other dimensions. The most significant case was the Netherlanders', whose punctuations were the most different between the personal and professional domains.

Several implications for teacher training have been already pointed out in this section, namely the need to focus on intercultural awareness and attitudes and to cater for self-learning. These goals could be achieved more easily by upgrading IC to the category of macrocompetence (Barros \& Kharnásova, 2012), by approaching IC in a comprehensive manner across the curriculum, and by raising awareness of the theoretical rationale explaining IC to make the link between philosophy and practice more explicit (Garrido \& Álvarez, 2004).

\section{Conclusions}

In this study we have attempted to clarify the relationship between IC and teacher training by describing the IC profile of a group of European student teachers. Our plans for future research, in order to overcome the obvious limitations of the present study, include testing the IC profile of a larger population, especially in relation to other non-European locations (beginning with data already collected from students from Japan, Brazil and Argentina, which were withdrawn from this study to limit its scope), to go beyond the inevitably limiting Westerner bias of this research. Another immediate line of research will involve datacollection through direct assessment instruments to neutralise the possible influence of social 
desirability on self-assessment and compensate for respondents' possible inaccuracies in their reports of their own behavioural choices (Arasaratnam \& Doerfel, 2005). Further research is needed in order to, precisely, treat IC as a macrocompentence, as exposed above.

\section{References}

Aguado, T., Ballesteros, B. \& Malik, B. (2003). Cultural diversity and school equity. A model to evaluate and develop educational practices in multicultural education contexts. Equity and Excellence in Education, 36(1), 50-63.

Alkan, M. \& de Vredee, E. (1990). Education in a Plural Society: A Survey of the Professional Opinions of Teachers in Europe. Amsterdam: Euras.

Alonso-Belmonte, I. \& Fernández-Agüero, M. (2013). Enseñar la competencia intercultural. In Y. Ruiz de Zarobe \& M. L. Ruiz de Zarobe (Eds.), Enseñar Hoy una Lengua Extranjera (pp. 182-220). London: Portal Education.

Alonso-Belmonte, I., Fernández-Agüero, M., Garrote, M. \& Morcillo, E. (2014, November). Análisis del perfil intercultural del profesor de segundas lenguas en formación. Paper presented at the 15th International Conference of the Spanish Association of Language and Literature Education. Valencia, Spain.

Alred, C., Byram, M. \& Fleming, M. (2003). Intercultural Experience and Education. Clevedon: Multilingual Matters.

Arasaratnam, L. A. \& Doerfel, M. L. (2005). Intercultural communication competence: Identifying key components from multicultural perspectives. International Journal of Intercultural Relations, 29, 137-163.

Ashwill, M. A. \& Duong, T. H. O. (2009). Developing globally competent citizens. In D. K. Deardorff (Ed.), The Sage handbook of Intercultural Competence (pp. 141-178). Thousand Oaks, CA: Sage.

Barros García, B. \& Kharnásova, G. M. (2012). La interculturalidad como macrocompetencia en la enseñanza de lenguas extranjeras: revisión bibliográfica y conceptual. Porta Linguarum, 18, 115-31.

Breidbach, S. (2003). Plurilingualism, Democratic Citizenship in Europe and the Role of English. Council of Europe, Language Policy Division, Strasbourg. Retrieved 24 December 2015 from http://www.coe.int/t/dg4/linguistic/Publications_EN.asp.

Byram, M. (1997). Teaching and Assessing Intercultural Communicative Competence. Clevedon: Multilingual Matters.

Byram, M. (Ed.) (2000). Routledge Encyclopaedia of Language Teaching and Learning. London: Routledge.

Byram, M. (2009). Intercultural Competence in foreign languages: The intercultural speaker and the pedagogy of foreign language education. In D. K. Deardorff (Ed.), The Sage Handbook of Intercultural Competence (pp. 321-332). Thousand Oaks, CA: Sage.

Byram, M. \& Fleming, M. (1998). Language Learning in Intercultural Perspective. Approaches through Drama and Ethnography. Cambridge: Cambridge University Press.

Byram, M., Gribkova, B. \& Starkey, H. (2002). Developing the Intercultural Dimension in Language Teaching. A Practical Introduction for Teachers. Strasbourg: Council of $\begin{array}{lllll}\text { Europe. } & \text { Retrieved } & 24 & \text { December } & 2015\end{array}$ http://lrc.cornell.edu/director/intercultural.pdf.

Byram, M. (Ed.), Neuner, G., Parmenter, L., Starkey, H. \& Zarate, G. (2003). Intercultural Competence. Strasbourg: Council of Europe. Retreived 16 December 2015 from 
http://www.coe.int/t/dg4/linguistic/Publications_EN.asp.

Byram, M. \& Phipps, A. (2007). Languages for Intercultural Communication and Education. Clevedon: Multilingual Matters.

Byram, M. \& Zarate, G. (1997). Defining and assessing intercultural competence: some principles and proposals for the European context. Language Teaching, 29, 14-18.

Cavalli, M., Coste, D., Crişan, A. \& van de Ven P. H. (2009). Plurilingual and Intercultural Education as a Project. Strasbourg: Council of Europe, Language Policy Division.

Chen, G. M. \& Starosta, W. J. (1996). Intercultural Communication Competence: A synthesis. In B. Burleson (Ed.), Communication Yearbook 19 (pp. 353-383). Thousand Oaks, CA: Sage.

Chen, G. M. (2005). A model of global communication competence. China Media Research, $1,3-11$.

Clouet, R. (2012). Studying the role of intercultural competence in language teaching in upper secondary education in the Canary Islands, Spain. Onomazein, 26(4), 309-334.

Collier, M. J. (2005). Theorizing cultural identification. In W. B. Gudykunst (Ed.), Theorizing about Intercultural Communication (pp. 235-256). Thousand Oaks, CA: Sage.

Costa, C. (2011). Intercultural competence: a major issue in foreign language teacher training? In A. Witte, T. Harden, A. Witte, \& T. Harden (Eds.), Intercultural Competence; Concepts, Challenges, Evaluations (pp. 127-139). London: Peter Lang.

Council of Europe. (2001). Common European Framework of Reference for Languages: Learning, Teaching, Assessment. Strasbourg: Council of Europe.

Deardorff, D. K. (Ed.) (2006). Identification and assessment of intercultural competence as a student outcome of internationalization. Journal of Studies in International Education, 10, 241-266.

Deardorff, D. K. (Ed.) (2009). The Sage Handbook of Intercultural Competence. Thousand Oaks, CA: Sage Publications.

Dogra, N. (2007). The views of medical education stakeholders on guidelines for cultural diversity teaching. Medical Teacher, 29(2-3), e41-e46.

Dooly, M. \& Villanueva, M. (2006). Internationalisation as a key dimension to teacher education. European Journal of Teacher Education, 29(2), 223-240.

Dunn, W., Kirova, A., Cooley, M. \& Ogilvie, G. (2009). Fostering intercultural inquiry in subject-area curriculum courses. Canadian Journal of Education, 32(3), 533-557.

Fantini, A. E. (1997). New Ways in Teaching Culture. Alexandria, VA: TESOL.

Fantini, A. E. (2000). A central concern: Developing intercultural competence. SIT Occasional Paper Series, 25-42.

Garrido, C. \& Álvarez, I. (2006). Language teacher education for intercultural understanding. European Journal of Teacher Education, 29(2), 163-179.

Gifford, C., Gocsal, A., Rado, B., Gonçalves, S. \& Wołodźko, E. (2009). Intercultural Learning for European Citizenship. European Commission's Department of Education and Culture. Retrieved 24 December 2015 from http://www.interculturallearningandcitizenship.eu.

Hammer, M. R. \& Bennett, M. J. (2001). The intercultural development inventory Manual. Version 2. Portland, OR: Intercultural Communication Institute.

Hammer, M. R., Bennett, M. J. \& Wiseman, R. (2003). Measuring intercultural sensitivity: The intercultural development inventory. International Journal of Intercultural Relations, 27(4), 421-443.

INCA Project Team. (2004). INCA Assessee Manual. Leonardo da Vinci VII Project. Retrieved 24 December 2015 from https://ec.europa.eu/migrantintegration/index.cfm?action=media.download\&uuid=2A9DBC62-915D-2DF1- 
BB29CABD750B1B42.

Kealey, D. J. (1989). A study of crosscultural effectiveness: Theoretical issues, practical applications. International Journal of Intercultural Relations, 13, 349-370.

Kramsch, C. (1993). Context and Culture in Language Teaching. Oxford: Oxford University Press.

Lanas, M. (2014). Failing intercultural education? 'Thoughtfulness' in intercultural education for student teachers. European Journal of Teacher Education, 37(2), 171-182.

Lázár, I. (2003). Incorporating Intercultural Communicative Competence in Language Teacher Education. Strasbourg: European Centre for Modern Languages, Council of $\begin{array}{lllll}\text { Europe. } & \text { Retrieved } & 24 & \text { December } & 2015\end{array}$ http://archive.ecml.at/documents/pub123bE2003_Lazar.pdf.

Lázár, I., Huber-Kriegler, M., Lussier, D., Matei, G. S. \& Peck, C. (Eds.) (2007). Developing and Assessing Intercultural Communicative Competence; A Guide for Language Teachers and Teacher Educators. Strasbourg: European Centre for Modern Languages, Council of Europe. Retrieved 24 December 2015 from http://archive.ecml.at/mtp2/publications/B1_ICCinTE_E_internet.pdf.

Martin, J. N. (1987). The relationship between student sojourner perceptions of intercultural competencies and previous sojourn experience. International Journal of Intercultural Relations, 11(4), 337-355.

Martinelli, S. (Coord.) (2000). Intercultural Learning T-kit. Strasbourg: Council of Europe, European Youth Center. Retrieved 24 December 2015 from http://pjpeu.coe.int/en/web/youth-partnership/t-kit-4-intercultural-learning.

Moran, P. R. (2001). Teaching Culture: Perspectives in Practice. Scarborough, ON: Heinle \& Heinle.

Prechtl, E. \& Davidson-Lund, A. (2007). Intercultural competence and assessment: perspectives from the INCA Project. In H. Kotthoff \& H. Spencer-Oatey (Eds.), Handbook of Intercultural Communication (pp. 467-490). Berlin and New York: Mouton de Gruyter.

Ruben, B. D. (1977). Guidelines for crosscultural communication effectiveness. Group and Organization Studies, 1, 334-354.

Ruben, B. D. (1989). The study of cross-cultural competence: Traditions and contemporary issues. International Journal of Intercultural Relations, 13, 229-240.

Ruben, B. D. \& Kealey, D. J. (1979). Behavioral assessment of communication competency and the prediction of crosscultural adaptation. International Journal of Intercultural Relations, 3, 15-48.

Seelye, H. N. (1996). Experiential Activities for Intercultural Learning, Vol 1. Yarmouth, ME: Intercultural Press.

Sercu, L. (2006). The foreign language and intercultural competence teacher: The acquisition of a new professional identity. Intercultural Education, 17(1), 55-72.

Sercu, L. (2010). Assessing intercultural competence: More questions than answers. In A. Paran \& L. Sercu (Eds.), Testing the Untestable in Language Education (pp. 17-34). Clevedon: Multilingual Matters.

Spitzberg, B. \& Changnon, G. (2009). Conceptualizing intercultural competence. In D. Deardorff (Ed.), The Sage Handbook of Intercultural Competence (pp. 1-52). Thousand Oaks, CA: Sage.

Taylor, M., Brander, P., Cárdenas, C., Gomes, R. \& de Vicente Abad, J. (1995). All Different, All Equal. Education Pack. Strasbourg: Council of Europe, European Youth Centre. Retrieved 24 December 2015 from http://www.eycb.coe.int/edupack.

Ting-Toomey, S. (1999). Communicating Across Cultures. New York: Guilford Press. 
Vez, J. M. (2009). Multilingual education in Europe: Policy developments. Porta Linguarum, 12, 7-24.

Villegas, A. M. \& Lucas, T. (2002). Preparing culturally responsive teachers; Rethinking the curriculum. Journal of Teacher Education, 53(1), 20-32.

Williams, T. R. (2005). Exploring the impact of study abroad on students' intercultural communication skills: Adaptability and sensitivity. Journal of studies in international education, 9(4), 356-371.

Young, T. \& Sachdev, I. (2011). Intercultural communicative competence: exploring English language teachers' beliefs and practices. Language Awareness, 20(2), 81-98.

\section{Acknowledgements}

We would like to thank our colleagues who contributed to the collection of the data: Valeria Arva, Sander Kamphuis, Oya Katırc1, Henny Oude Maatman, John O’Regan, Alice Sukdolová and Ludmila Zemková.

1 In this article, IC is preferred to other similar terms such as Intercultural Communicative Competence because it attracts most agreement among researchers and academics. Nevertheless, in the literature, the term ' $I C$ ' coexists with -and is sometimes used interchangeable with-others such as 'pluriculturality', 'multiculturality' and 'transculturality' (see Deardorff, 2009 for an overview).

${ }^{2}$ These dimensions have been recently revised and integrated into a model of global communication competence (Chen, 2005).

${ }^{3}$ The INCA project can be found here:

https://ec.europa.eu/migrant-integration/index.cfm?action=furl.go\&go=/librarydoc/the-inca-projectintercultural-competence-assessment

${ }^{4}$ Turkey is included in this study as it is a transcontinental Eurasian country.

${ }^{5} \mathrm{We}$ assume a confidence interval of $95 \%$.

\section{Authors' biodata:}

Marta Garrote is a Lecturer in education at Universidad Autónoma of Madrid. She is a member of the research groups Discourse Analysis and Intercultural Communication and Technology Enhanced Language Learning. She has a PhD in Linguistics and her main research lines are corpus linguistics, development of language resources, teacher training and EFL.

Email: marta.garrote@uam.es

María Fernández Agüero currently works as an ELT lecturer at Universidad Autónoma of Madrid and belongs to the research group Discourse Analysis and Intercultural Communication (DAIC).. Her main research interests include second language teaching and learning, bilingual education and content and language integrated learning (CLIL).

To cite this article:

Garrote Salazar, M., \& Fernández Agüero, M. (2016). Intercultural competence in teaching: Defining the intercultural profile of student teachers. Bellaterra Journal of Teaching \& Learning Language \& Literature, 9(4), 41-58. DOI: http://dx.doi.org/10.5565/rev/jt13.670 